\title{
Caríssimos leitores,
}

No atual contexto, deparando-me com a folha de papel e pensando no que escrever, confesso da dificuldade em pesar e comedir as palavras, que não os deixasse na turva dúvida do impasse e os caminhos que poderiam tomar a pesquisa no Brasil. Mas ao me deparar com os artigos que contemplam esta edição, senti-me motivada e esperançosa, em virtude das ricas abordagens publicadas na edição desta revista pelos seus autores. Os trabalhos trazem no seu bojo, a riqueza criativa e bem elaborada, a respeito do constitucionalismo contemporâneo e as políticas públicas, que acima de tudo rememora ou reforça a força normativa da Constituição Brasileira, e de seguirmos em frente contribuindo com o pensamento crítico e social dos nossos leitores.

Dada tal relevância, toda a discussão ou debate realizado nos discursos acadêmicos, demonstram que o ser humano é o centro dos debates e o trabalho é um direito fundamental e social. A abordagem dada pelos autores nos seus artigos tem abrangência interdisciplinar quando alinha o direito com a teoria do Estado, do direito administrativo e das políticas públicas, destacando o papel dos cidadãos com o seu entorno e o meio ambiente. Portanto, o artigo AÇÃO POPULAR AMBIENTAL ENQUANTO INSTRUMENTO DE PROMOÇÃO DA SUSTENTABILIDADE NAS CONTRATAÇÕES PÚBLICAS, significa a materialização dessa circularidade entre as áreas sociais e aplicadas. O trabalho sobre A POLÍTICA PÚBLICA DE INOVAÇÃO TECNOLÓGICA E A COOPERAÇÃO UNIVERSIDADE-EMPRESA: REVISITANDO A TEORIA DA AGÊNCIA é um marco importante para o direito, pois consolida cada vez mais no discurso acadêmico a necessidade de aproximar-se da tecnologia por meio de inovações nas políticas públicas que podem ser repensadas na era da tecnologia.

No âmbito da teoria do direito é relevante analisar a matéria de financiamento de campanha na ótica do Supremo Tribunal Federal, por isso a grandiosidade do texto: FINANCIAMENTO DE CAMPANHA E JURISDIÇÃO CONSTITUCIONAL NA ÓTICA DO STF: PARA UMA ANÁLISE CRÍTICA DA RELAÇÃO DIREITO E MORAL À LUZ DO DEBATE HART-DWORKIN. Delineando um pouco mais o desafio das políticas públicas no Brasil, a partir da Constituição Federal de 1988, temas como a proteção multinível de direitos humanos no CASO MARGARIDA MARIA ALVES: uma demonstração do desafio brasileiro à proteção multinível de direitos humanos são explorados com propriedade, assim como as políticas educacionais envolvendo A QUALIDADE DO ENSINO JURÍDICO NO BRASIL: ALGUMAS TRANSFORMAÇÕES NECESSÁRIAS. Ao encontro disso, reforça-se ainda mais a necessidade de continuar revisitando trabalhos categóricos como: PARA ESTUDAR POLÍTICAS PÚBLICAS: ASPECTOS CONCEITUAIS, METODOLÓGICOS E ABORDAGENS TEÓRICAS. E por fim, mas não esgotando os percalços jurídicos e os liames com a ética e a moral o artigo PERSPECTIVAS SOBRE POLÍTICAS PÚBLICAS DE INCLUSÃO DIGITAL E FOMENTO ÀS 
CIDADES INTELIGENTES O ATIVISMO JUDICIAL NA REVELAÇÃO DA VALORIZAÇÃO DO TRABALHO HUMANO NA ORDEM ECONÔMICA CONSTITUCIONAL. Importa ainda aqui referenciar, da importância do homem não ser escravo de si próprio, nem do outro, por meio da escrita e da leitura. Principalmente, concretizando o discurso da democracia e da diversidade, não esvaziando a Constituição brasileira, nem a tornando um mero pedaço de papel.

\section{Boa leitura a todos!}

Rosane Teresinha Carvalho Porto

Doutora em direito - Editora adjunta 